\title{
MODAL INTONATION FEATURES OF CROWD SCENES IN THE OPERETTA "O OLMASYN, BU OLSUN” (“Not That, So This”) BY U. HAJIBEYLI
}

\author{
Naiba Shakhmamedova
}

PhD in Art History, Associate Professor;

ORCID: 0000-0001-7622-7146; e-mail: naibe.shahmemmedova@mail;

Azerbaijan National Conservatory, Baku, Azerbaijan

\section{Abstract}

The article analyses the features of the crowd scenes' structure in the operetta " $O$ olmasyn, bu olsun" (1910) by the outstanding composer Uzeyir Hajibeyli (1885-1948), who founded the Azerbaijani professional composer school at the beginning of the 20th century. In this operetta rich in comic imagery, the composer's style is reflected in choral scenes influenced by harmonious recitatives and musical patterns and analyzed as a philosophical sphere of reflection of events in the comical plane. He also interprets the development of the operetta genre as a genre of contemporary music in the professional traditions of Western European music in Azerbaijan, as well as the features of intonation that are relevant in Azerbaijani folk music in terms of its structure and thematic focus.

The purpose of the research is to analyze the modal features of the operetta "O olmasyn, bu olsun". For this, the variety of characters available in the work, the line of development of these characters as an issue to study the compatibility of the inner world of characters, given both emotionally and comically, come to the fore. It is also noteworthy that the comparison of moods and intonations in the events taking place in the crowd scenes is naturally reflected here.

The research methodology draws attention to the comparative and historical analysis of music theory and history of music, axiological and cultural approaches. Here, the principle of using texts in musical scenes reflects the originality of the composer's style. Our analysis made it important to consider the research of various researchers who adhere to the principle of secularism.

The scientific novelty of the research lies in the fact that for the first time in U. Hajibeyli's operetta "O olmasyn, bu olsun", an extensive analysis of fret features in crowd scenes with different editions was carried out. The emergence of these features also serves as an example for musicians and composers working in the field of musical composition.

Conclusions. The analysis of the modal intonations' features of crowd scenes in the operetta by U. Hajibeyli "O olmasyn, boolsun" shows the clarity of the intonation principles in Azerbaijani folk music from the point of view of the correspondence of images. This aspect also shaped the composer's intonation concept. Musical materials suitable for the composer's comedy scene explain the different situations of the protagonist. The article draws attention to the combination of images and choral performance used in public scenes, for example, the 
combination of mood and intonation. The use of historical, musical theory, composition, modal intonation features on the public stage is more consistent with the fret concept created by the composer U. Hajibeyli.

Keywords: crowd scenes in an operetta; modal-mugham features; modal-intonation concept; musical genres; analytical principles

\section{Introduction}

Prominent Azerbaijani composer, musicologist, scientist, publicist, playwright, pedagogue, and public figure, founder of modern "Azerbaijani professional music and national opera" Uzeyir Hajibeyli has been a genius artist and founder of the Azerbaijan School of Professional Composition since the early twentieth century gained fame (Shteinpress \& Yampolsky, 1966, p. 103). Interesting and attractive aspects of his work were the formation of the composer's broad outlook. "Apart from the genres of opera, operetta, oratorio, song, etc., he also wrote an arithmetic textbook, which is necessary for the education of children, as well as the "Turkish-Russian and Russian-Turkish dictionary". He translated the story "Shinel" [Overcoat] from Russian into Azerbaijani (Gasimova \& Bagirov, 1984, p. 47). "The composer began to engage in this activity mainly after graduating from the Gori Teachers' Seminary, i.e., in 1904" (BabayevaTagiyeva, 2011, p. 68). The works of U. Hajibeyov, who left deep traces in the history of Azerbaijani composition, are considered to be the pearls of world music. The musical comedy "O olmasyn, bu olsun" that we are looking at was written by the composer in 1910. This was the second work of the composer in the genre after the musical comedy "Husband and Wife". "It should be noted that the comedy genre, an ancient genre, has been promoted in Western Europe since the Renaissance and by travelling artists, formed in the Italian theatre in the 18th century, and later as an operetta genre in professional theatre and music of German, French and other nations. has also found its embodiment." (Zilberkwit, 1988, p. 277). It was at the beginning of the 20th century that U. Hajibeyli's appeal to the operetta genre, as well as other genre works, was a cultural event of the time. Among the musical works written by the composer, musical comedies have been loved by listeners since their inception and have retained their reality. At first, the musical comedy "O olmasyn, bu olsun" had three scenes. However, the composer's "Bath" scene was added to this work in 1915, which was perfected as it was staged. Thus, the work had 4 scenes. U. Hajibeyli used Azerbaijani folk music in the work, and ghazals of the medieval Azerbaijani poet M. Fuzuli in arias and choirs. The title of the work was first mentioned in the April 7, 1911 issue of the "Kaspi" newspaper. The premiere of the musical comedy "O olmasyn, bu olsun" took place on April 25, 1911, at the Mayilov Brothers Theater in Baku (now the Azerbaijan State Academic Opera and Ballet Theatre named after Mirza Fatali Akhundov). The conductor of the theatrical performance was the author of the musical comedy Uzeyir Hajibeyov himself. The libretto of the comedy was first published in 1912 in Baku by the Orujov Brothers Printing House. After that, it appeared in several staged versions of musical comedy. The work was translated into various languages and staged in many countries around the world. "Based on this comedy, the famous Azerbaijani film director, honoured art worker of the Azerbaijan SSR Huseyn Seyidzade made his first film in 1956" (Rahimli, 2005, p. 139). 


\section{Main research material}

Printed versions of the libretto of the work existed in 1912-1916 in 3 parts and 1918 in 4 parts in the Arabic alphabet. However, the note was published in 1959 at the Institute of Architecture and Art of the Academy of Sciences of the Azerbaijan SSR during the Soviet period.

However, many scientific and cultural events held in our country in modern times created newly printed versions of this work. An example of this is the publication of the Mashadi-lbad operetta piano by composer Sardar Farajov in 2007, followed by the Heydar Aliyev Foundation and the Friends of Azerbaijani Culture Foundation in Baku in 2008.

U. Hajibeyli's musical comedy "O, olmasyn bu olsun" not only reflects many critical characters but also attracts attention with its crowd scenes. In contact with the choral numbers in the operetta, the embodiment of different images, presented in a comic and satirical manner, is distinguished by its importance. The numbered presentation of music on the stage shows its programmatic nature. Choir numbers also play a special role in the work. The chorus numbers reflected here are mainly from 2 aspects. The first of these can be seen as arias and duets sung by comic characters of choral numbers, and the second as performances of critical objects directed against those characters. The music used here on public stages is also noteworthy in terms of its accompaniment. In particular, the principle of choral numbers and their accompaniment has expanded in the work of U. Hajibeyli in the following years and has had a unique impact on the work of many Azerbaijani composers in the twentieth century. "Among them are the works of such composers as G. Garayev, J. Hajiyev, J. Jahangirov, R. Shafag, S. Mutallibov, N. Aliverdibeyov, E. Karimova" (Rustamova, 2012, p. 7).

In the musical comedy "O olmasyn, bu olsun" written by the composer in 1910$11 \mathrm{~s}$, which was staged many times since its inception, U. Hajibeyli used both bureaucratic-despotic and people's remaines of bourgeois society during the use of choral numbers on public stages. "Azerbaijani folk music, dances, mugham pieces, etc. are widely reflected in the musical material used in the curtains and numbers of this work" (Zohrabov, 1991, p. 6).

In general, in the editions of the work published in 2007-2008, the operetta consists of 24 performances in 4 acts. The operetta contains 10 performances, including "Antrakt" in the 1st act, 8 in the 2nd act, 1 in the 3rd act, and 6 in the 4th act. Choir numbers used in public scenes include "Prologue" after "Overture", "They say there will be a wedding", (Deyirler ki toy olacaq) "Mashadi-lbad's fight" (Meshedi iBadin davasi), "Choir of coaches", (Qocularin xoru) "Nothing like this", (Bele ish olmaz) "It can't be that you" (Boyle olmazki sen), "Congratulations of the people to MashadiIbadi" (Camaatin Meshedi Ibadi tebrik etmesi), "In the bath”, (Hamamin ichinde), "Let's go and tell the judge" (Gedek qaziya deyek).

However, the modal-intonation features present in the work are more closely connected with the lyrical, lyrical-comic, and enthusiastic characters of the characters, along with the choral numbers in the mass scenes. "Composer, U. Hajibeyov in these scenes widely used rast, shur and segah intonations" (Shikhaliev, 2015, p. 13). "Un- 
doubtedly, it was also influenced by the traditional Azerbaijani professional music of the oral tradition" (Zohrabov, 1996, p. 3).

The choir number used in the "Prologue" is addressed to the eternal heroes of the poem "Leyli and Majnun" by the great Azerbaijani poet Mohammad Fuzuli: Leyli and Majnun: "Who cares, says the creature that Leyli was a stranger, this is nonsense, this legend has fallen into the mouths of the people" begins with the words (Hajibeyov, 2007, p. 111).

The number is available in Andante in 3/4 size. The 1-period musical sentence used here is repeated for the second time in a variant. However, the repetition of the variant ends with the imitation of the last phrase given in the female voices and the postlude of the accompaniment. Here the composer refers to the sound of a shur maqam using shur intonations.

\section{Imaclis}

\section{№2 Proloq}

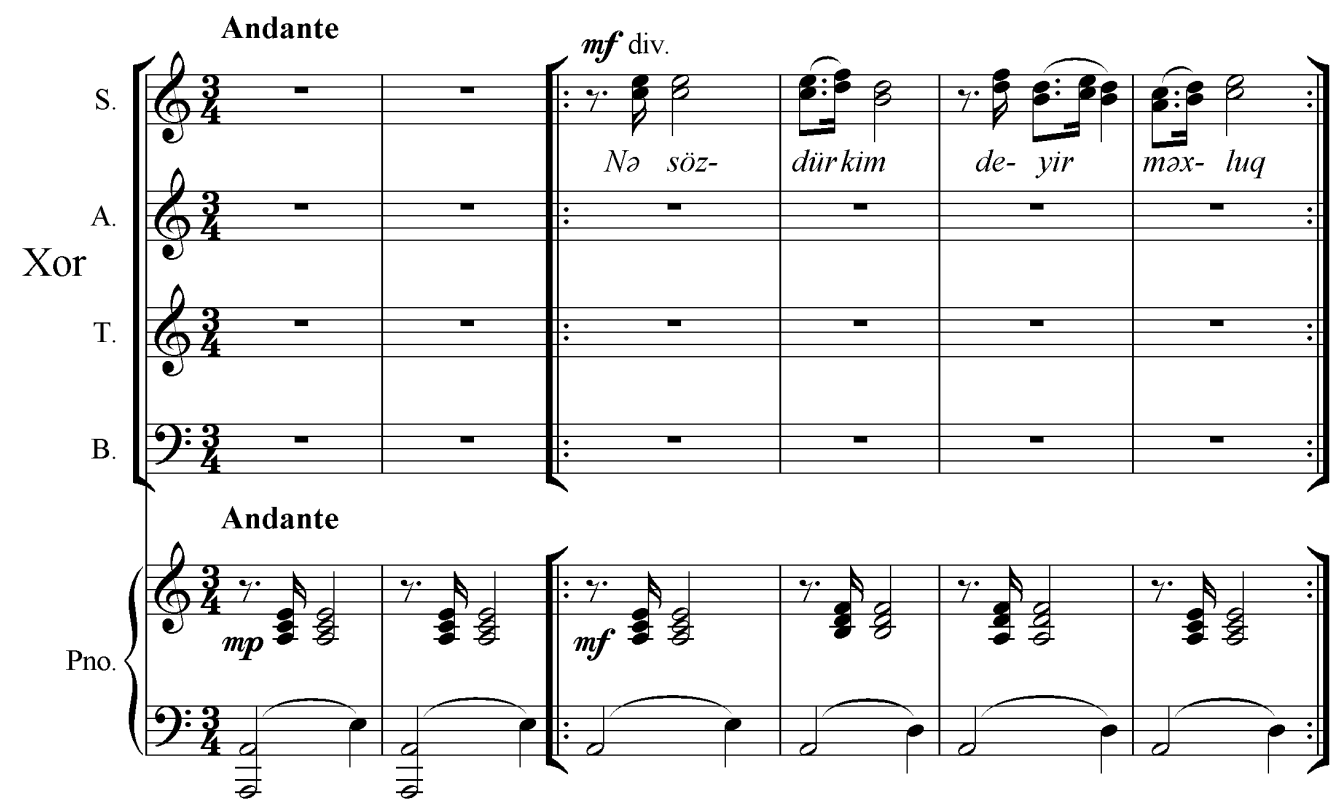

In the first act, two choral numbers are used in the mass scene, such as "They say there will be a wedding", "Mashadi-lbad's fight".

Choir Scene 8, entitled "They say there will be a wedding", is presented in Allegretto in the form of a simple 2-part $(a+b)$ couplet with a square period of $6 / 8$. The main comic characters of the work, such as Hasangulu bey, Rza bey, Asgar bey, Hasan bey, Rustam bey, Mashadi Ibad are reflected. These images, in turn, act as melodicepisodic dialogue phrases in the question sentence with the pieces of music to which they belong to. The response sentences are completed by the men choir. Shahnaz in- 
tonations are noticeable during the performance. These intonations correspond to the sound of the A shur moment. The phrases repeated in the 1st period and the chorus's answer refer to the sura of the A shur. However, in the second period, the repeated phrases are $\mathrm{E}$ shur-shahnaz, and the chorus's response is again expressed by referring to the A tonal sound. (O Maye Pardesi)

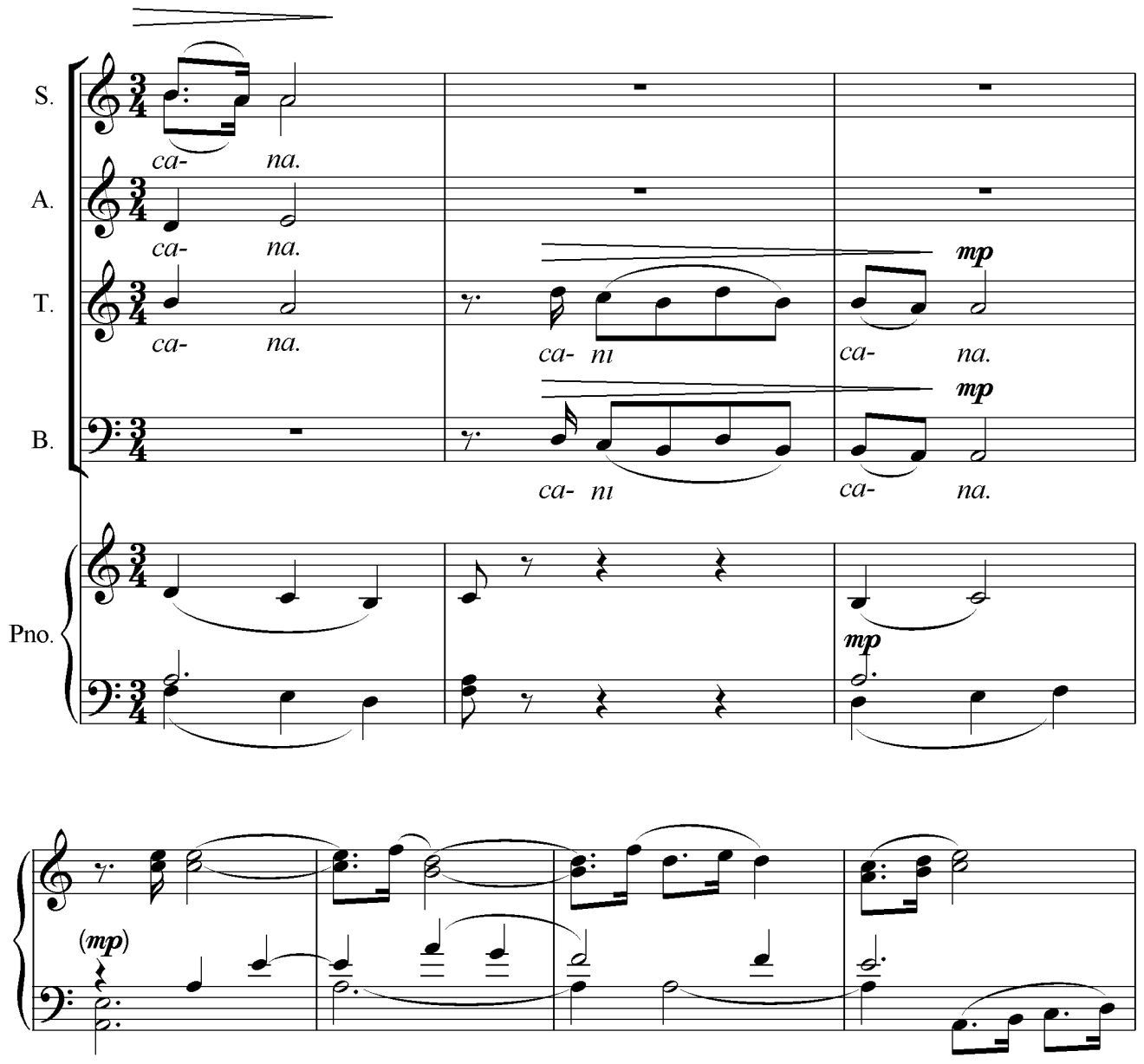

The scene consisting of the performance of Hasan bey, Mashadi-lbad, and the choir No. 9 called "Mashadi-lbad's case" is given in 6/8 time in Allegro. This number consists of only 1-period sentences, starting with 2-digit input bars. Here, mostly segah intonations correspond to the sound of A segah. The first sentence, which began with the speech of Hasan Bey, and the second sentence of the Sikasteyi-Fars, which belongs to the A segah, show itself about the leading tone of the maya (tonal sound). However, at the end of each of the 2 phrases, the main tone of the $A$ segah is referred to. 


\section{№8. Xor: "Deyirlar ki, toy olacaq..."}
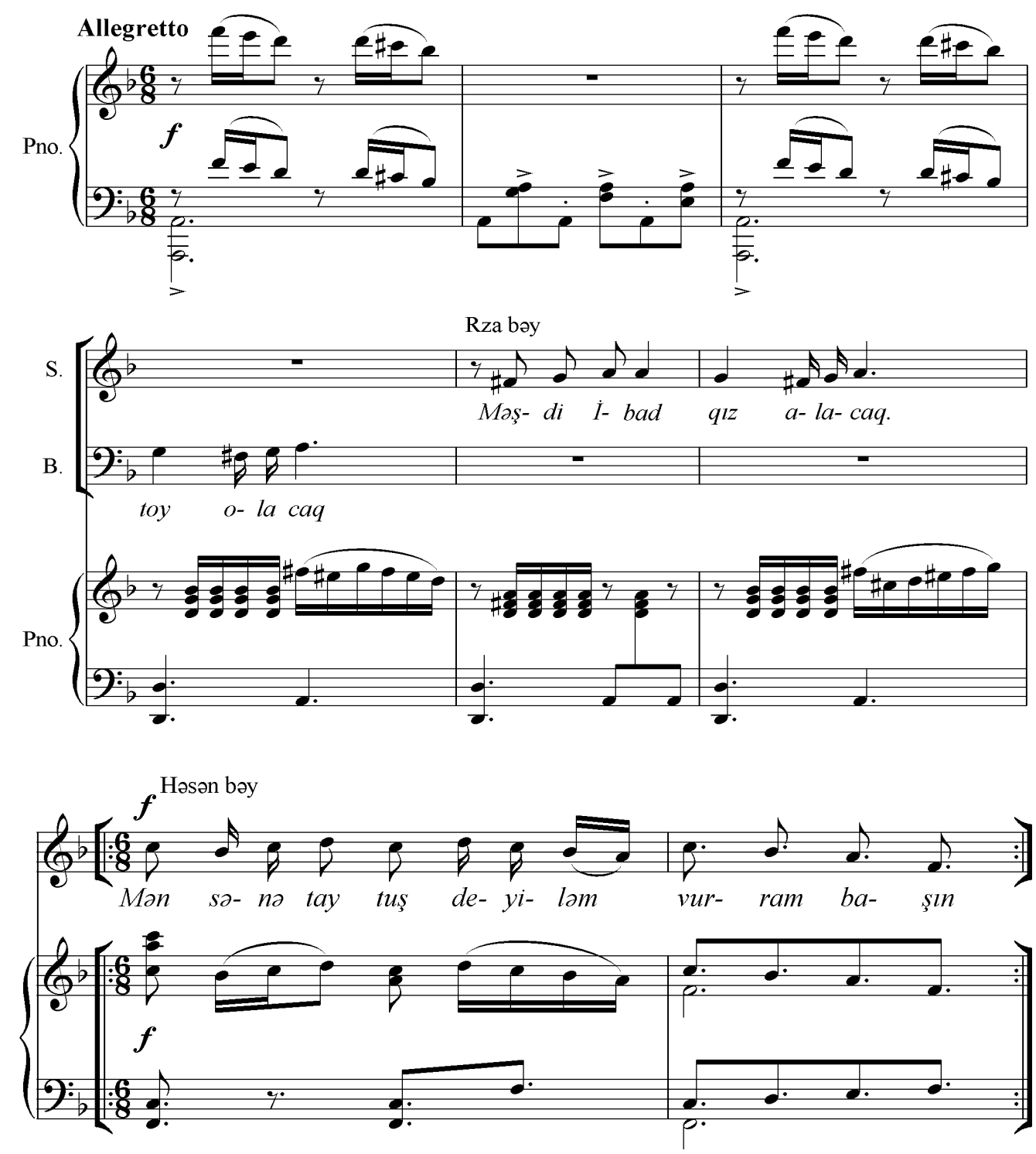

The male choir used in this issue draws attention to the variant image of the same musical phrase. In the speech of Mashadi-lbad, in the first sentence, reference is made to the veil of fa belonging to $A$ segah. The second phrase again shows itself by referring to the leading tone. At the end of each of the two phrases, the main tone of the $A$ segah is referred to again. 
(Məşədi İbad)

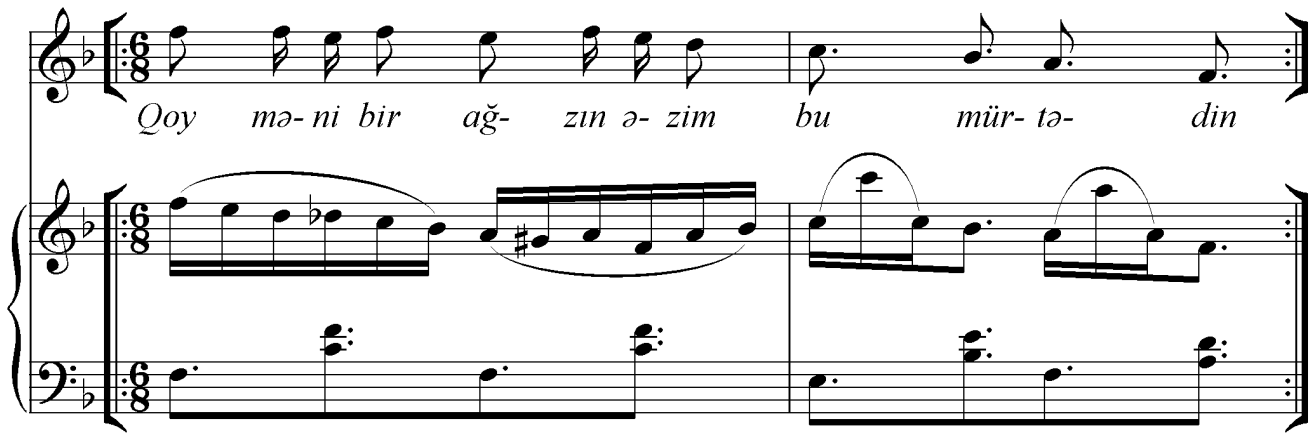

In the second act of the operetta, "Aries Choir" is presented with its artistic aspect and a male choir in a kind of angry, emotional, and comic image. "Aries Choir No. 14" is a duet of Sarvar and Gulnaz, as well as Sarvar's exchange with the choir. Mainly couplet-rondo structure: $(a+b+c+b 1)$ Tempo di Marcia, tempo is presented in 2/4 time. A 12-digit square period is used in this section. Right intonations are heard during the melody. These intonations correspond to the sound of the right moment. Each of the periods in the sections is repeated twice. The end of the question sentence ends in the upper apex tone of the base belonging to the $\mathrm{H}$ in Rast, and the answer sentence ends in the bases sound (tonal) of the B Rast.

\section{№14. Qoçuların xoru}

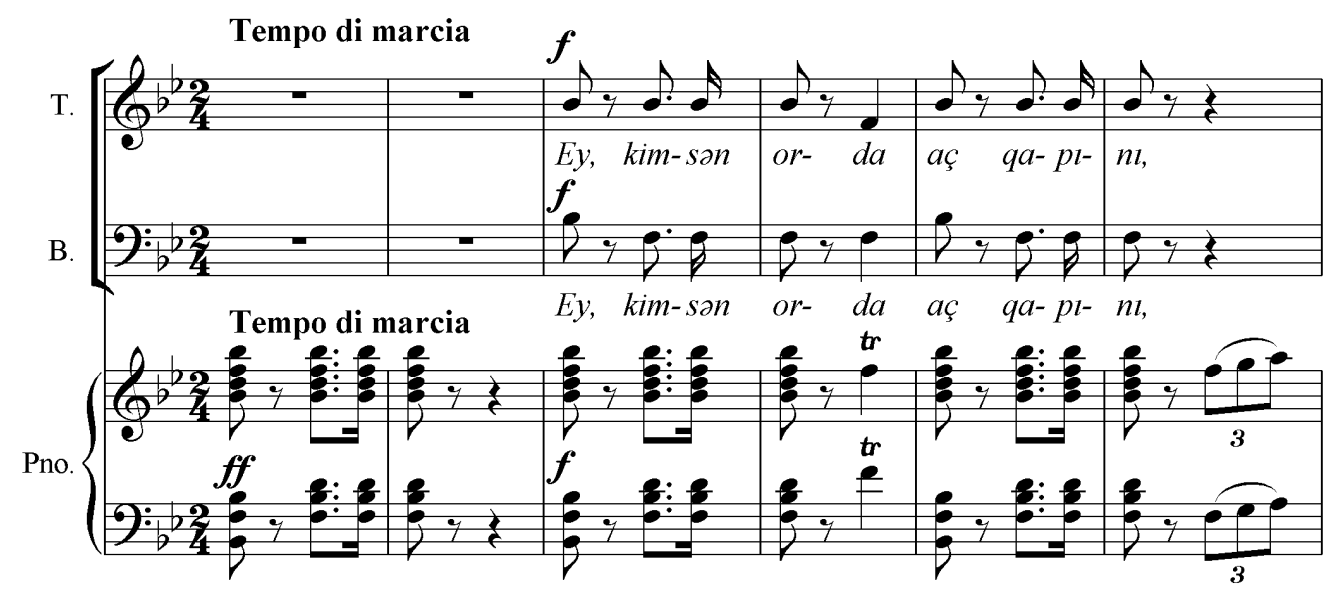

In part B, the duet of Sarvar and Gulnazin is visible in the party of choir voices and accompaniment. Here, in the question sentence, especially the intonations of the Ushshag fret show themselves. The end of this sentence is connected with the Ushshag fret of the right hemisphere. The answer is based on the Sikasteyi-Fars mode. 
However, the end of the sentence is again connected with the tonal base sound of B Rast.

Then, in section c, Sarvar's appeal to the coaches is reflected. The part used in this section is repeated twice. The question sentence of the part contains 4 syllables and reflects the intonations of the Hijaz. This, in turn, is due to the D Hijaz sound belonging to the left council. The answer refers to the left-hand part of the left council. However, during the second repetition of the same part, the answer is expressed in the expanded form of the sentence and finally manifests itself in the modulation of Bayati-shiraz intonations. The end of the part is based on the bases sound of the left Bayati-shiraz. Then the transition to section $b$ occurs again. This section ends with a choir performance.
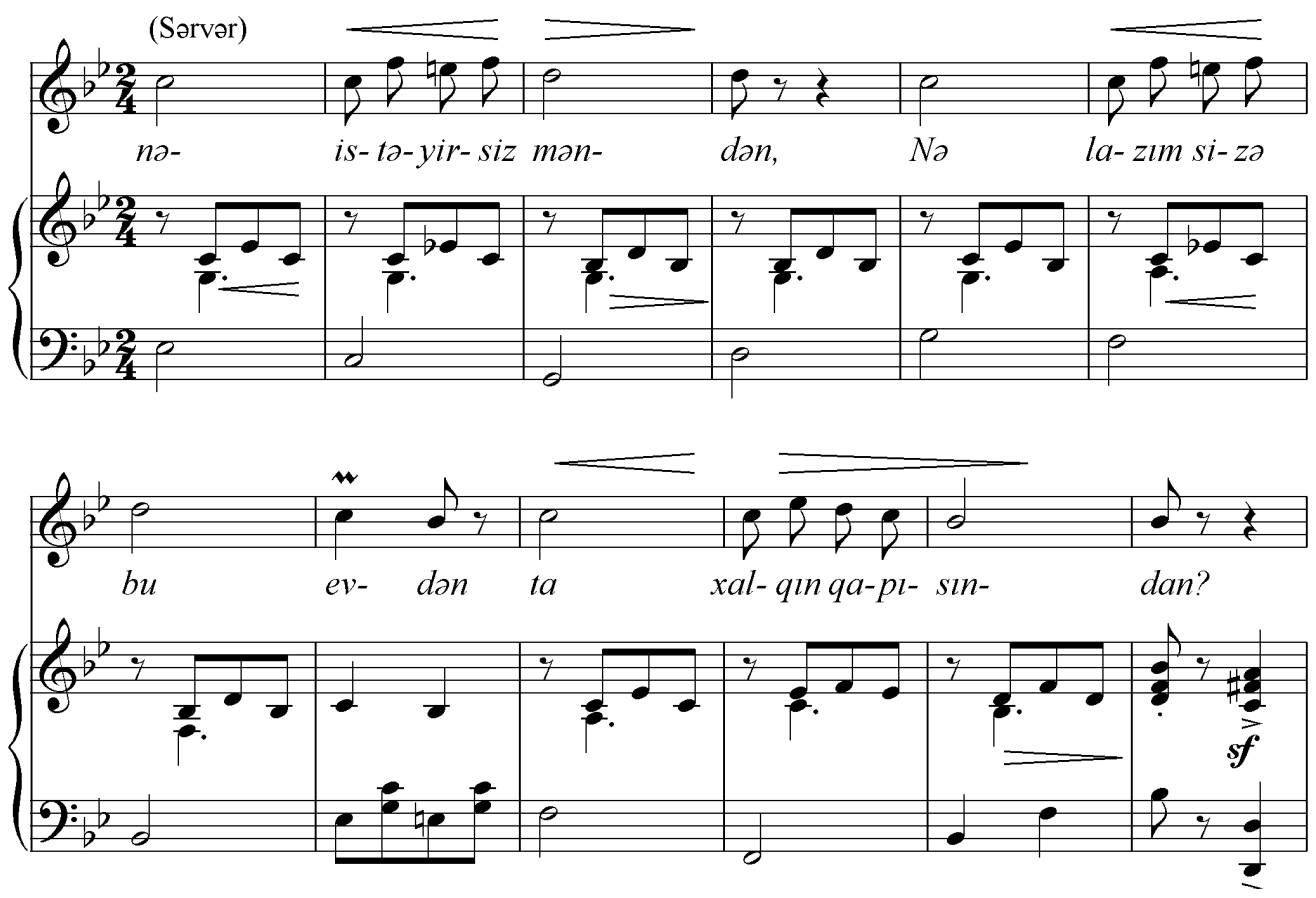

One of the special places in the operetta is occupied by choir number 14 "No such thing". This reflects the moderato tempo and 3/4 scale. The choir number consists mainly of 1 period and is repeated in the part of the mixed choir and Mashadi Ibad. The melodic text, performed by a mixed choir after the introductory verses, clearly reflects the condemnation of Mashadi Ibad in the face of a kind of people. The question sentence of the period is repeated twice by the choir. Shur intonations are heard during the sounds. These intonations correspond to the sound of the A Shur moment. During the performance of the question sentence, the first time refers to the bases sound to the A council, and the second time refers to the D Shur-shahnaz sound belonging to the A council. In the phrases that exist in the answer sentence, there is a transition to the sound of A Shur do. At the end of this melodic sentence, the base sound is referred to again. 


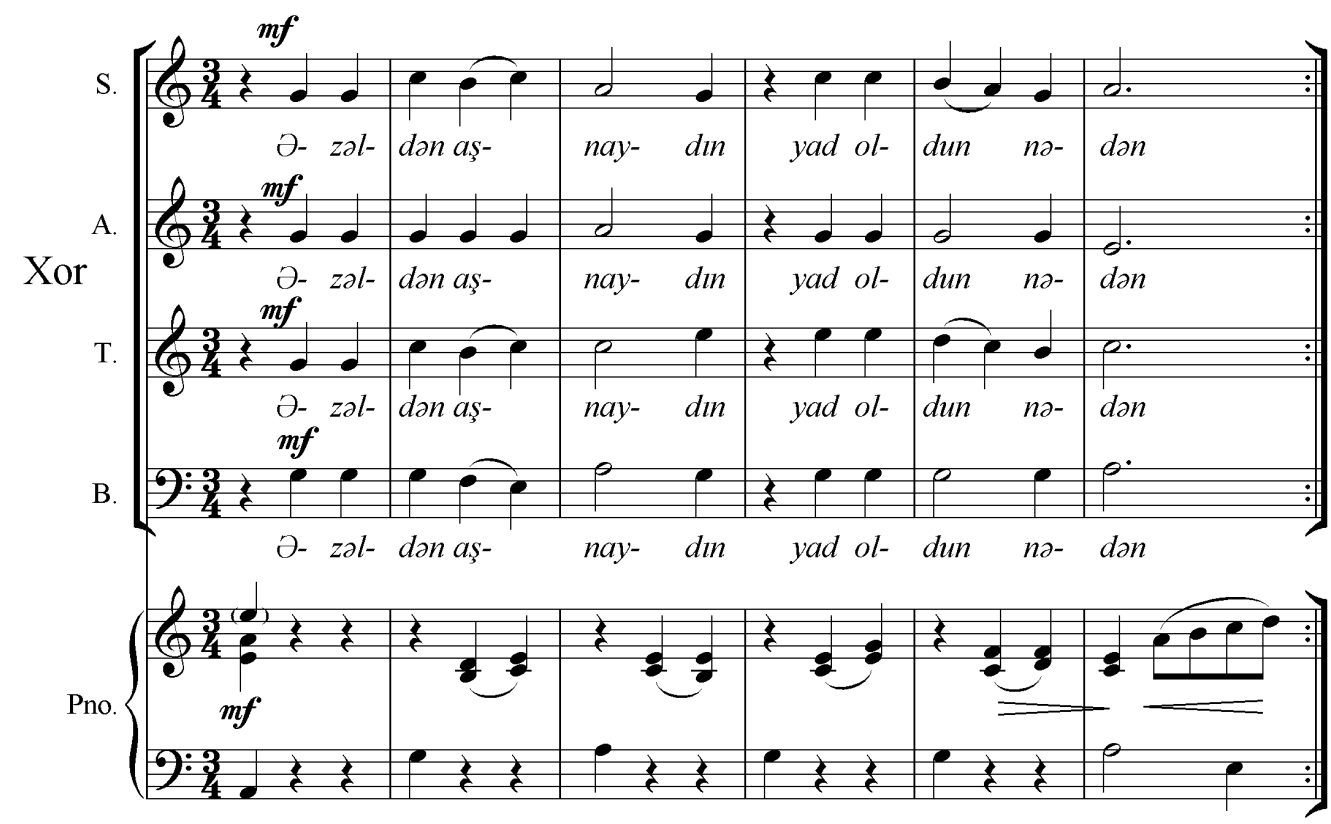

The men's choir and Mashadi Ibad's performance, which is given as number 17 in the work, attracts attention with the chorus "It's not like that, you". Here the tempo di Marcia and the 6/8 dimension are reflected. This number is based on the small couplet shape structure with $a+b$ structure. Part a of the number is based on a melodic sentence consisting of 1 period. This melodic sentence is based on intonations. This is in line with the sound of the moment.

\section{№17. Xor: "Böyla olmaz ki san..."}

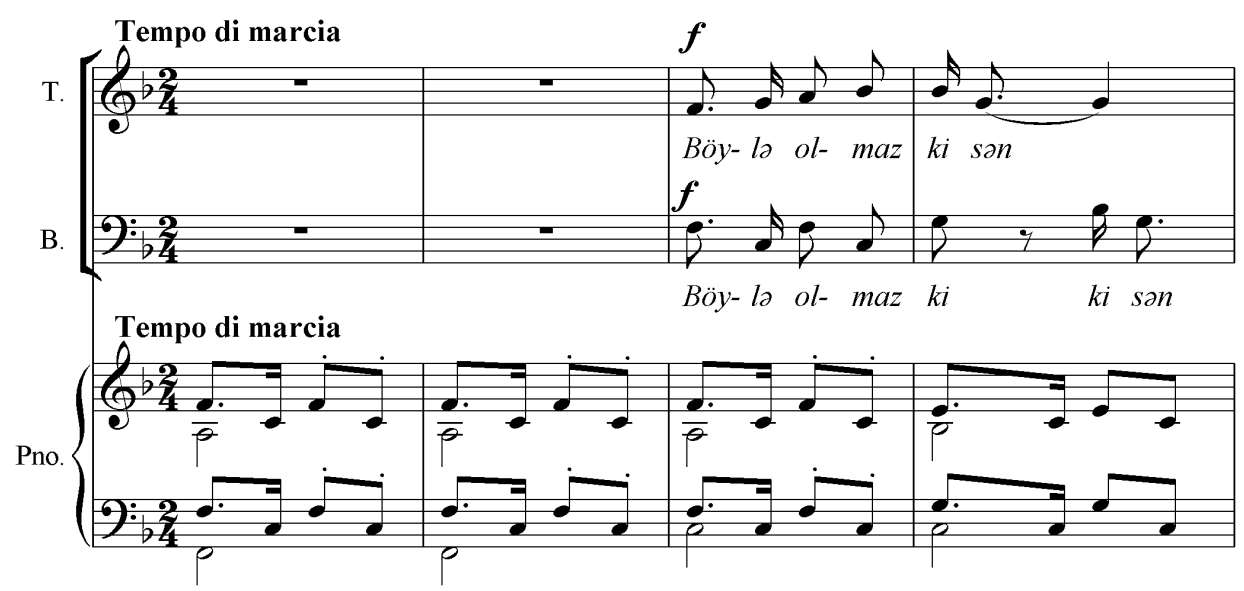


Mashadi Ibad's speech covers section b in nuance f. Here, the intonations of the Rast belong to the veil of the F Erag, which sounds one octave higher than the base sound of the Rast. Here the question manifests itself in the curtain of the end of the sentence si bemol Husseini. The answer is first in Mashadi Ibad's party, then in the chorus repeating this party. The end of this period also ends with the base sound belonging to the $\mathrm{F}$ Rast point.

In the operetta, the public's congratulations to Mashadi-lbadi are given as number 18 as the "Choir and Mashadi-lbad" scene. It starts with entry bars of the performance entry bars. The melody used in the performance is then repeated in mixed choral sounds and then repeated in Mashadi-lbad's party in the form of a square period. However, the same period is played in a varied way after the Mashadi-lbad's part, again in choral voices. Right intonations are mainly used here. These intonations correspond to the sound of the right moment. Here, in chorus sounds, reference is made to the lower lead tone of the $\mathrm{C}$ base sound at the end of the question sentence, and the bases sound in the answer sentence. Only in Mashadi-lbad's party, at the end of the question sentence, reference is made to the lower quartet of the bases sound, and again to the $C$ base sound in the answer sentence. The $2^{\text {nd }}$ act ends with this scene.

\section{№18. Xor va Maşadi İbad}

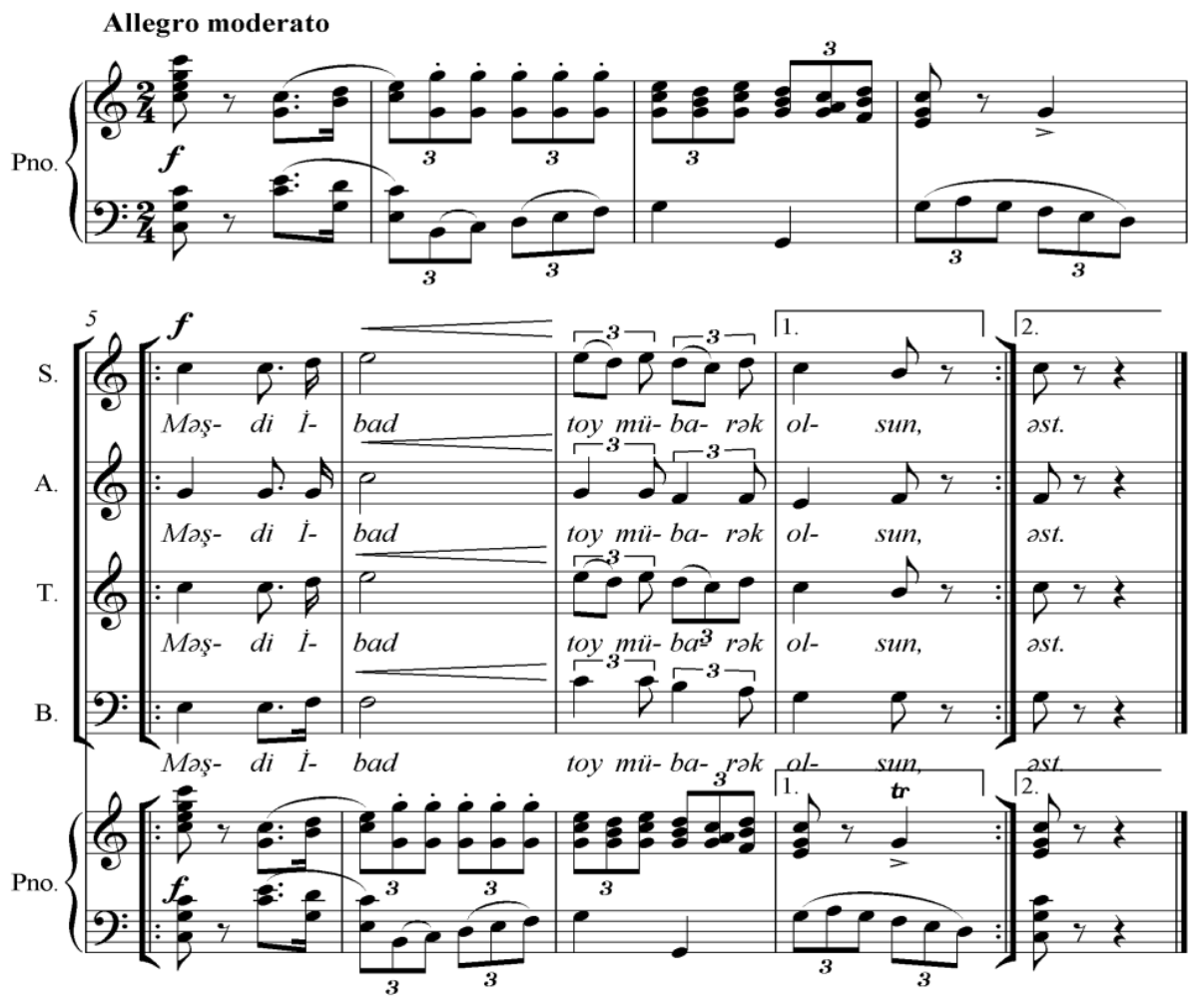


In the third act of the operetta (3rd assembly) only one choral number called "In the bathroom" is given. This piece is in the form of one part and is presented as a choir number 19 in the form of song and dance. The song and dance based on that part are repeated, first as an instrumental interlude and then in the male choir. Here you can hear $6 / 8(3 / 4)$ chorus intonations on con moto. These intonations correspond to the sound of the F Shur mode. At the end of the period's question sentence, the C Hijaz, which belongs to the $\mathrm{F}$ Shur, is referred to, and in the answer sentence, the A Zamin-Khara and $\mathrm{F}$ base sound are referred to. Depending on the content of the operetta, the performance scene is reflected after the first performance of this choir. Then the choir and accompaniment repeat the second answer sentence of the part. At the end of the chorus, the answer sentence is repeated with instrumental performance in the form of a postlude.

\section{№19. Xor: "Hamamin içindo..."}
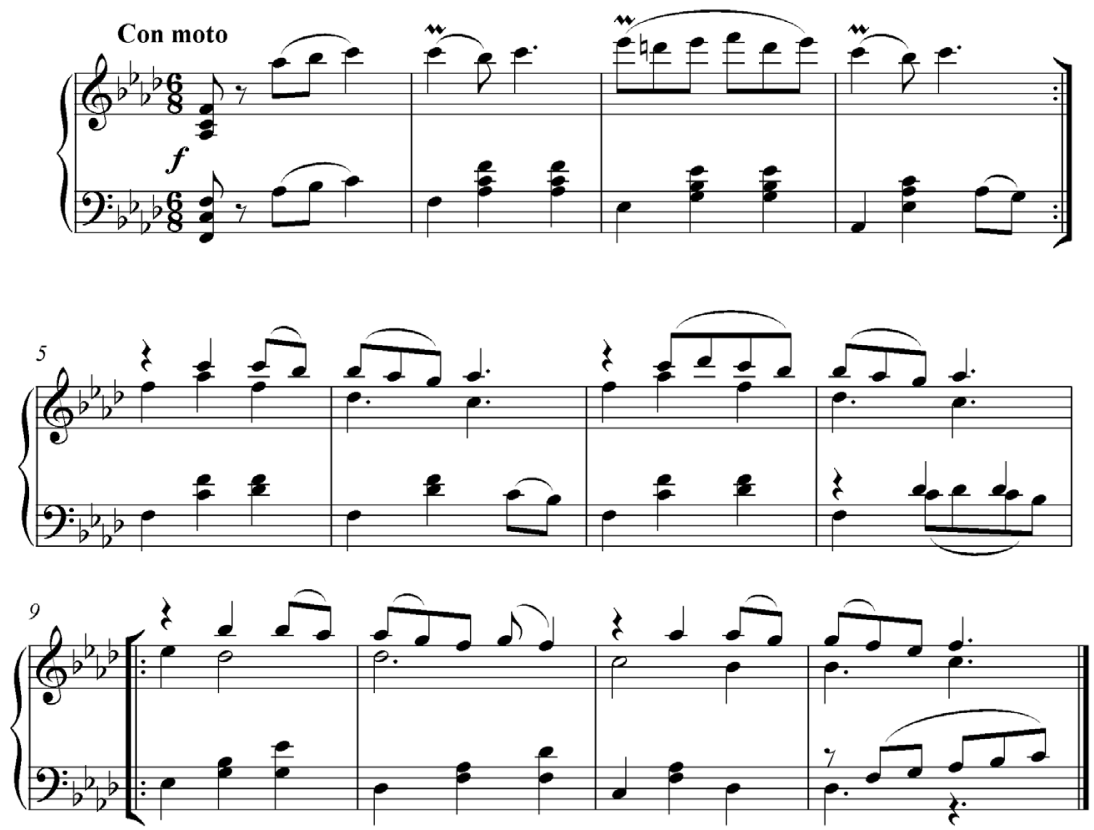

Here, in the 4th act, the choir number "Let's go to judge" is again presented in Allegretto grazioso in 6/8 meter. This scene, which is composed of a mixed choir, Mashadi-lbad, and servant Sanam's question and answer, is again reflected as number 1, as a 1-period melodic sentence. The question sentence of the period is repeated in only 4 bars. However, the answer sentence is expanded to include the chorus question, Mashadi-Ibad, and servant Sanam's reply. After the repetition of the periodic sentence in the chorus in Mashadi-lbad's party, these reply replications are declamatory. It is presented here in con moto in 6/8 (3/4) time. During this period, mostly Shur intonations are heard. The intonations of the period corresponding to the sound of the A Shur fret. Here, the question sentence refers to the $\mathrm{E}$ Hijaz belonging to the A council, and the answer sentence refers to the base sounds. 

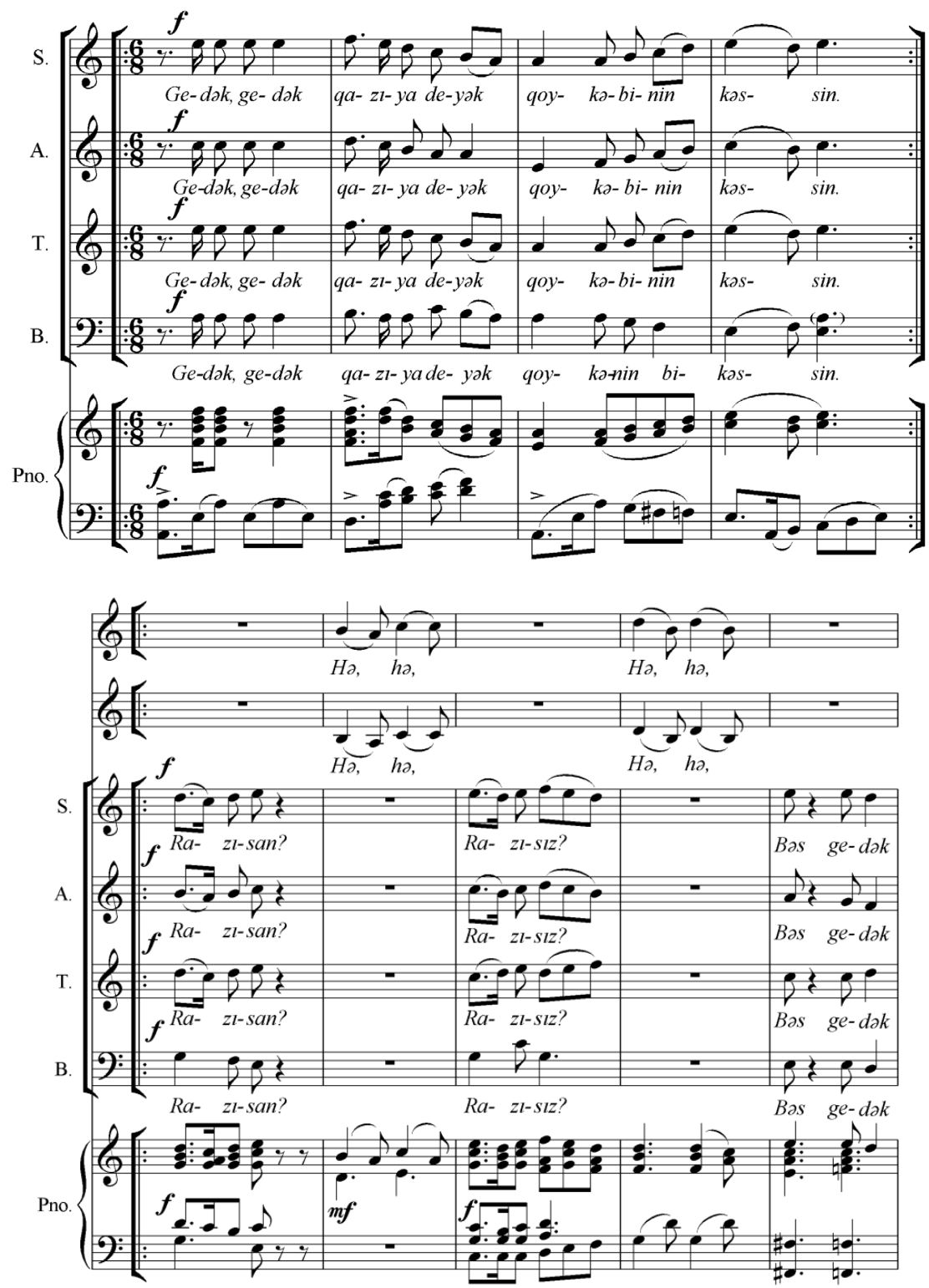

The end of this act and operetta is completed by the final chorus. The final number 24 is represented by a mixed choir and a choir number "O olmasyn bu olsun" performed by Mashadi-Ibad. Here the couplet variant form shows itself in the form $a+b$. Choral sounds are mainly reflected in tempo di Marcia, 2/4 time.

Rast intonations are heard during the melody. These intonations correspond to the $G$ sound of the Rast mode of encounter. Here, in section a, the question phrase based on D Sikesteyi-Fars, and the answer phrase bases on the base sound of the mode. 


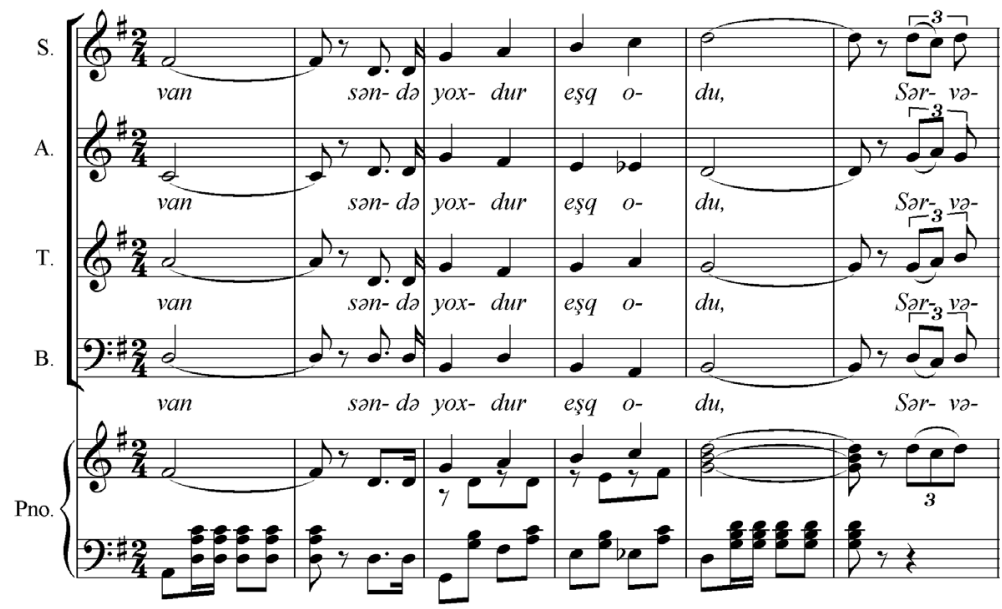

In part $b$ of the period, the question begins with Mashadi-lbad's party. Then the answer sentence is reflected in the mixed chorus sounds. In Mashadi-lbad's party, the question sentence refers to them based on $\mathrm{G}$ sound in Rast mode $\mathrm{H}$ sound of Ushshak, and the answer sentence refers to the base sound performed by the choir. Here the whole repetition of the period is repeated in the performance of the choir. The work ends with a final chorus culminating in the ff nuance, about the G Erag sound of the Rast mode.

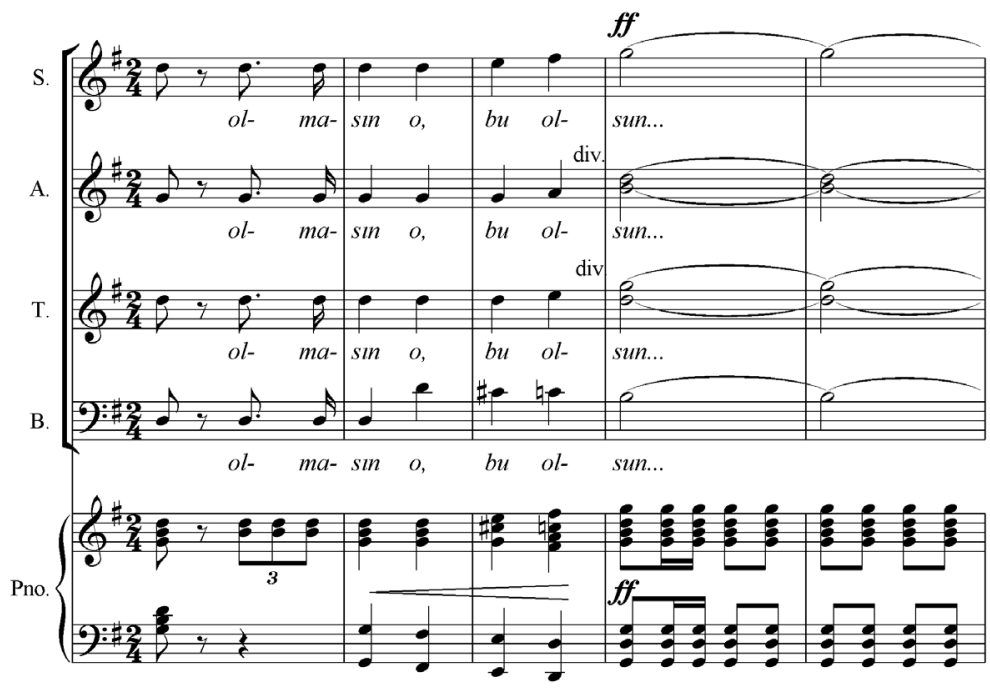

\section{Conclusions}

Thus, we see the importance of modal intonation structure of choral numbers in the mass scenes of the operetta "O, olmasyn bu olsun". Namely, these features of U. Hajibeyli's compositional style are an example for today in terms of compositional 
style. In this musical comedy, the positive and negative aspects of the real events that took place in the real life of the Azerbaijani people at the beginning of the last century are reflected in the musical language in both comic and satirical terms, which gives the composer a broad outlook. Through the language of music, he manages to reveal the nature of the various images that exist between the masses and the people. These aspects resonate with us, and now the composition is an example for our school.

\section{References}

Babayeva-Tagiyeva, A. F. (2011). Musiqi Dünyası [World of Music] [in Azerbaijani].

Gasimova, S., \& Bagirov, N. (1984). Azərbaycan Sovet Musiqi Jdəbiyyatı [Azerbaijan Soviet Music Literature]. Maarif [in Azerbaijani].

Hajibeyov, U. (2007). O Olmasin, Bu Olsun [If Not That One, Then This One] [Piano score]. Çinar-cap. Rahimli, I. (2005). Azərbaycan Teatr Tarix [History of Azerbaijan Theater]. Çaşıoğlu [in Azerbaijani]. Rustamova, A. (Ed.). (2012). Azərbaycan Bəstəkarlarının Xor Jsərlərinin Təfsirində Fortepiano Müşayiztinin Rolu [The Role of Piano Accompaniment in the Interpretation of Choral Works of Azerbaijani Composers]. Mütərcim [in Azerbaijani].

Shikhaliev, I. (2015). Ladovaya Teoriya Azerbaidzhanskoi Muzyki [Modal Theory of Azerbaijani Music] [in Russian].

Shteinpress, B. S., \& Yampolsky, I. M. (1966). Entsiklopedicheskii Muzykal'nyi Slovar' [Encyclopedic Music Dictionary] (2 ${ }^{\text {nd }}$ ed.). Sovetskaya entsiklopediya [in Russian].

\section{ОСОБЛИВОСТІ ЛАДОВОЇ ІНТОНАЦІЇ МАСОВИХ СЦЕН ОПЕРЕТИ «О ОЛМАСИН, БУ ОЛСУН» («НЕ ТА, ТАК ЦЯ») У. ГАДЖИБЕЙЛІ}

\section{Наїба Шахмамедова}

доцент, доктор філософії з історії мистецтв;

ORCID: 0000-0001-7622-7146; e-mail: naibe.shahmemmedova@mail.ru

Азербайджанська національна консерваторія, Баку, Азербайджан

\section{Анотація}

У статті аналізуються особливості будови масових сцен в опереті «О олмасин, бу олсун» (1910) видатного композитора Узеїра Гаджибейлі (1885-1948), який заснував азербайджанську професійну композиторську школу на початку XX ст. У цій, багатій на комічну образність опереті, композиторський стиль відображений в хорових сценах під впливом гармонійних речитативів і музичних патернів і аналізується як філософська сфера відображення подій в комічному плані. Він інтерпретує розвиток оперети як жанру 
сучасної музики в професійних традиціях західноєвропейської музики в Азербайджані, а також особливості інтонації, які актуальні в азербайджанській народній музиці з точки зору їі структури і тематичної спрямованості.

Мета дослідження - проаналізувати ладові особливості в опереті «О олмасин, бу олсун». Для цього на перший план виходить різноманіття наявних у творі образів, лінія розвитку цих образів як питання дослідження сумісності внутрішнього світу персонажів, заданих як в емоційному, так і в комічному плані. Примітно також, що тут закономірно відбивається зіставлення настроїв і інтонацій в подіях, що відбуваються в масових сценах.

Методологія дослідження ґрунтується на використанні порівняльного і історичного аналізу музичної теорії та історії музики, аксіологічного та культурологічного підходу. Принцип використання текстів в музичних сценах відображає своєрідність стилю композитора. Наш аналіз зробив важливим розгляд досліджень різних дослідників, які дотримуються принципу секуляризму.

Наукова новизна дослідження полягає в тому, що вперше в опереті У. Гаджибейлі «О олмасин, бу олсун» проведено аналіз ладових особливостей в масових сценах з різними редакціями. Поява цих особливостей також $є$ прикладом для музикантів і композиторів, які працюють з музичною композицією.

Висновки. Аналізособливостейладовихінтонацій масовихсценвоперетіУ. Гаджибейлі «О олмасин, бу олсун» показує ясність принципів інтонації в азербайджанській народній музиці з точки зору відповідності образів. Цей аспект також сформував інтонаційну концепцію композитора. Музичні матеріали, які підходять для комедійної сцени композитора, пояснюють різні ситуації головного героя. Стаття звертає увагу на поєднання образів і хорового виконання, використовуваних в публічних сценах наприклад, поєднання настрою та інтонації. Зрозуміло, що використання на публічній сцені історичної, музичної теорії, композиції, ладово-інтонаційних особливостей більше відповідає ладовій концепції, створеній композитором У. Гаджибейлі.

Ключові слова: масові сцени в опереті; ладо-мугамні особливості; ладово-інтонаційна концепція; музичні жанри; аналітичні принципи

\section{ОСОБЕННОСТИ ЛАДОВОЙ ИНТОНАЦИИ МАССОВЫХ СЦЕН ОПЕРЕТТЫ «О ОЛМАСЫН, БУ ОЛСУН» («НЕ ТА, ТАК ЭТА») У. ГАДЖИБЕЙЛИ}

\section{Наиба Шахмамедова}

доцент, доктор философии по истории искусств;

ORCID: 0000-0001-7622-7146; e-mail:naibe.shahmemmedova@mail.ru

Азербайджанская национальная консерватория, Баку, Азербайджан

\section{Аннотация}

В статье анализируются особенности строения массовых сцен в оперетте «О олмасын, бу олсун» (1910) выдающегося композитора Узеира Гаджибейли (18851948), основавшего азербайджанскую профессиональную композиторскую школу в начале XX в. В этой, богатой комической образностью оперетте, композиторский стиль 
отражен в хоровых сценах под влиянием гармоничных речитативов и музыкальных паттернов и анализируется как философская сфера отражения событий в комическом плане. Он интерпретирует развитие оперетты как жанра современной музыки в профессиональных традициях западноевропейской музыки в Азербайджане, а также особенности интонации, которые актуальны в азербайджанской народной музыке с точки зрения ее структуры и тематической направленности.

Цель исследования - проанализировать ладовые особенности в оперетте «О олмасын, бу олсун». Для этого на первый план выходит многообразие имеющихся в произведении образов, линия развития этих образов как вопрос исследования совместимости внутреннего мира персонажей, заданных как в эмоциональном, так и в комическом плане. Примечательно также, что здесь закономерно отражается сопоставление настроений и интонаций в событиях, происходящих в массовых сценах.

Методология исследования основывается на использовании сравнительного и исторического анализа музыкальной теории и истории музыки, аксиологического и культурологического подхода. Здесь принцип использования текстов в музыкальных сценах отражает своеобразие стиля композитора. Наш анализ сделал важным рассмотрение исследований различных исследователей, придерживающихся принципа секуляризма.

Научная новизна исследования заключается в том, что впервые в оперетте у. Гаджибейли «О олмасын, бу олсун» проведен анализ ладовых особенностей в массовых сценах с различными редакциями. Появление этих особенностей также служит примером для музыкантов и композиторов, работающих с музыкальной композицией.

Выводы. Анализ особенностей ладовых интонаций массовых сцен в оперетте у. Гаджибейли «О олмасын, бу олсун» показывает ясность принципов интонации в азербайджанской народной музыке с точки зрения соответствия образов. Этот аспект также сформировал интонационную концепцию композитора. Музыкальные материалы, подходящие для комедийной сцены композитора, объясняют различные ситуации главного героя. Статья обращает внимание на сочетание образов и хорового исполнения, используемых в публичных сценах, например, сочетание настроения и интонации. Понятно, что использование на публичной сцене исторической, музыкальной теории, композиции, ладово-интонационных особенностей больше соответствует ладовой концепции, созданной композитором У. Гаджибейли.

Ключевые слова: массовые сцены в оперетте; ладо-мугамные особенности; ладовоинтонационная концепция; музыкальные жанры; аналитические принципы 